\title{
IN VITRO STUDIES ON IMMUNOLOGICAL MECHANISM OF ANTIGENIC INFORMATION TRANSFER OF THE TONSIL.
}

\author{
AKIO IMAI, M.D. \\ Department of Otolaryngology, Niigata University School of Medicine Niigata
}

(Director: H. Ino, M.D.)

It is important to make the immunological role of the tonsil clear, comparing the responses of tonsil with those of the spleen and lymphnodes which are known as peripheral lymphatic organs.

These experiments were condutcd to learn whether the antigenic information in the tonsil induced the antibody formation of anothe lymphatic organs. The experimental procedures are as follows:

1) Adult rabbits were sensitized intravenously and peritonsillarlly with SRBC in vivo, and tonsil, spleeen and lymphnode cells were cultured in vitro. Simultaneously, non-sensitized spleen cells were cultured with sensitized tonsil cells, with sensitized spleen cells and with sensitized lymphnode cells.

2) 4 days after, the antibody forming cells (plaque forming cells) were meassured by Jerne's hemolytic plaque technique.

The following conclusions were drawn from this study:

1) Live cells of $42 \%$ were harvested after 4 -day culture.

2) PFC number per $10^{6}$ wore away to $1 / 2-1 / 10$, in both single culture and mixed culture.

3) On the whole, mixed culture was inclined to increase its number of PFC.

4) In the group of one-time i. v. sensitization, only IgM-PFC of tonsil increased in number in mixed culture.

5) In the group of repeated i. v. sensitization, every organ had the tendency of increase in number of $\mathrm{PFC}$.

6) In the group of peritonsillar sensitization, a small number of PFC was recognized in tonsil. Especially none of IgM-PFC was found in single culture, but mixed culture resulted ia appearance of PFC.

Discussions were done on the mechanism of the increase in number of PFC in mixed culture, and the ability of transfer of antigenic information of the tonsil.

A78-0528. 52060

\section{細胞培養による扁桃の抗原情報伝達系に関する研究}

\section{新潟大学医学部耳鼻咽喉科教室（主任：猪初男教授）}

今 井 昭 雄

\section{緒 言 \\ 近年免疫学の発展に伴ない，扁挑の免疫機能化関する 研究が種々行われている．著者らも既に扁挑の兔疫学的}

位置，局所免疼能に関する研究成績から,脾㟲、リンパ 節の免疫能と比較検討して, 扁桃を局所免疫能を営む末 梢性リンパ組織としてとらえてきた。. ${ }^{1223) 4)}$ 
特江最近のリンパ球の研究は, 細胞培養, 細胞学的検 索技術の向上に伴なつて急速に発達し，T-cell, B-cell 雨 者の起源や機能並びに両者の相互作用に関する報告は枚 挙にいとまがない しかし T-cell, B-cell の機能につい てはいまだ問題が残されており，今後の研究に俟つ点が 多い

扁桃に杍ける T-cell, B-cell およびマクロファージの 相互作用についてもいまだ定説はない，また，ヒトにお ける液性抗体産生に関する中枢性リンパ組織（鳥類のフ アブリシウス囊に相当する器官，家兔では虫垂にその倩 きを認めている報告がある゙少の存在が確認されていな 、現在, 扁桃を始めとする腸管付随リンパ組織の機能解 明がいそがれる。

扁桃は消化管上端口狭部に位置し，外来刺激に常にさ らされ，慢性炎症を有し，僄延感作の状態沉あるといら 特徴をもち，他の末梢性りンバ組織である脾臟やリンパ 節と違つた反応態度を示するのと推察される。

外部から取り込九だ抗原刺激に対する，個々のリンパ 組織の反忘樣式については既に報告したが，個々のリン ハN性臟器が抗原刺激に反応寸るとともに，この情報を他
のリンパ組織へ伝達し, 全身的に影響を与える能力, 様 式に違いがあるのではないだるらかといら点から侢桃の 特徵をとらえてみようと考え，実験動物として家鬼を用 いて次のような実験を行つた。すなわち，抗体産生細胞 の産生罒地として脾臟を選び，正常脾臟細胞を培養し， これに感作された扇桃細胞を混合して Jerne の抗体プ ラク法で，抗体産生細胞数の変化をみた，同時に，感作 された脾細胞リンパ節細胞についても同様の方法で培 塊し，扁桃細胞と比較した。

\section{実験材料および実験方法}
1）実験スケジュール
2）実験動物
3) 抗原
4）感作方法
5 ）血清抗体洒の測定
6）培養条件
7) 緗胞浮遊液調整法
8）培養細胞の採取
9）抗体産生細胞 (PFC) の測定
10）混合培盖群における PFC の換算，比較法

\section{PROCEDURE}
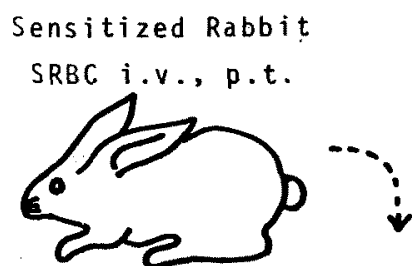

Single
(1)

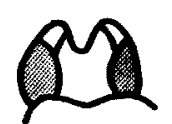

(2)

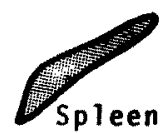

(3)

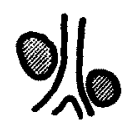

Lymphnode
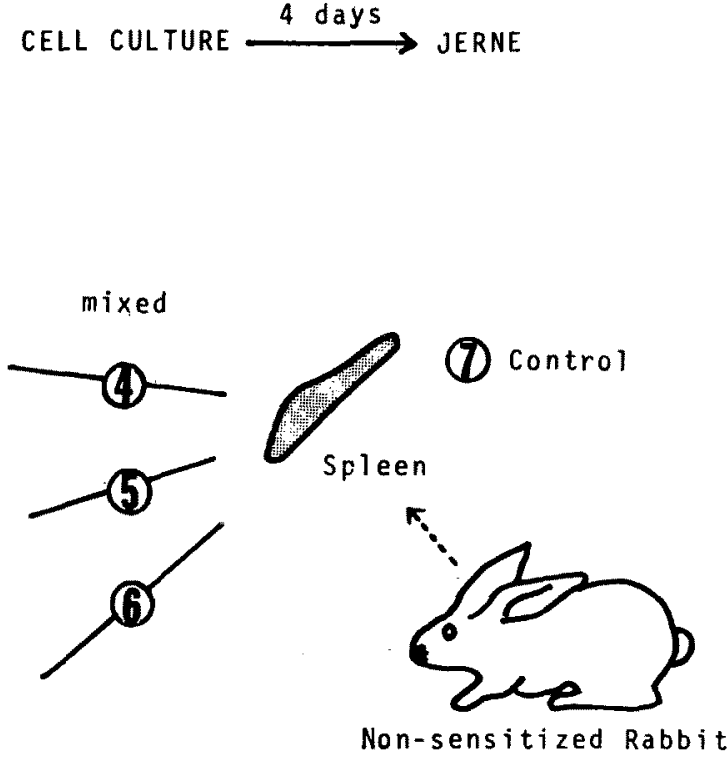

図 
1）実験スケジュール（図 1)

感作動物の扁桃細胞, 脾細胞, リンパ節細胞と, 非感 作正常脾細胞を採取, 単独培盖群 (Single Culture) と混 合培養群 (Mixed Culture) 招よび Control の 7 種の組 合せで培養を行った。

培羲 4 日目に各々について Jerne の hemolytic plaque technique による抗体産生細胞数を算定比較した.

\section{2) 実験動物}

成熟白色家鬼（体重 $2 \mathrm{~kg}$ 程度）

\section{3) 抗原}

補体結合反応用羊血球 sheep red blood cell, SRBC (東芝化学 K.K.)

使用前に生理食塩水で 3 回洗浄し，生理食塩水で $25 \%$ 赤血球浮遊液として使用。

4) 感作方法

(i) 静注感作群：1 回量 2ml 10ml, 1 回 6 回 (RABBIT No. 1-No. 20)

(ii) 扁桃周囲感作群：1 回量両側へ0.5ml ずつ, 1 回 3 回 (RABBIT No. 21 No. 24)

ネンブタール麻酔下に口腔内より扁桃赛質を通して扁
挑周用一局注.

感作は原則として週 1 回とした。

5 ）血清抗体価の測定 (血球凝集反応)

10倍から倍数稀釈した血清に $0.5 \%$ 羊血球生食浮遊液 等量加え, 室温に一夜放置後判定 ${ }^{(3)}$

6) 培養条件

(i) Medium: Eagle'MEM, glutamine, 10\%正常ウサギ 血清 (NRS), SM 100 $\mu \mathrm{g} / \mathrm{ml}$, PC-G 100 unit $/ \mathrm{ml}$, PH 7.2 (ii) 細胞漂度： $10 \times 10^{6} / \mathrm{ml}$ 亿細胞浮遊液を調整, 直径 $9 \mathrm{~cm} お よ ひ ゚ 2 \mathrm{~cm}$ のガラスシャーレにおのおの $10 \mathrm{ml}$, $2 \mathrm{ml}$ ずつ入れて培羡.

$0.7 \times 10^{6} / \mathrm{ml} \sim 34 \times 10^{6} / \mathrm{ml}$ の濃度で各細胞を培羡し 4 日後の細胞数を測定して，その絶対数および生存率を総 合すると，細胞濃度の低い培養はバラッキが大きく, 細 胞濃度が高くなると効率が悪くなる。したがって $10 \times$ $10^{6} / \mathrm{ml}$ 前後の細胞源度による培美を至適漲度とした。 ${ }^{8)}$ しかし，扁桃組織から細胞を採取する場合は，充分な細 胞数が得られず，扁桃単独培養群 では， $0.7 \times 10^{8} / \mathrm{ml}$ $4.5 \times 10^{6} / \mathrm{ml}$ 平均 $2.3 \times 10^{6} / \mathrm{ml}$ 程度の細胞数が 得 られ た.

HEMOLYTIC PLAQUE ASSAY, JERNE

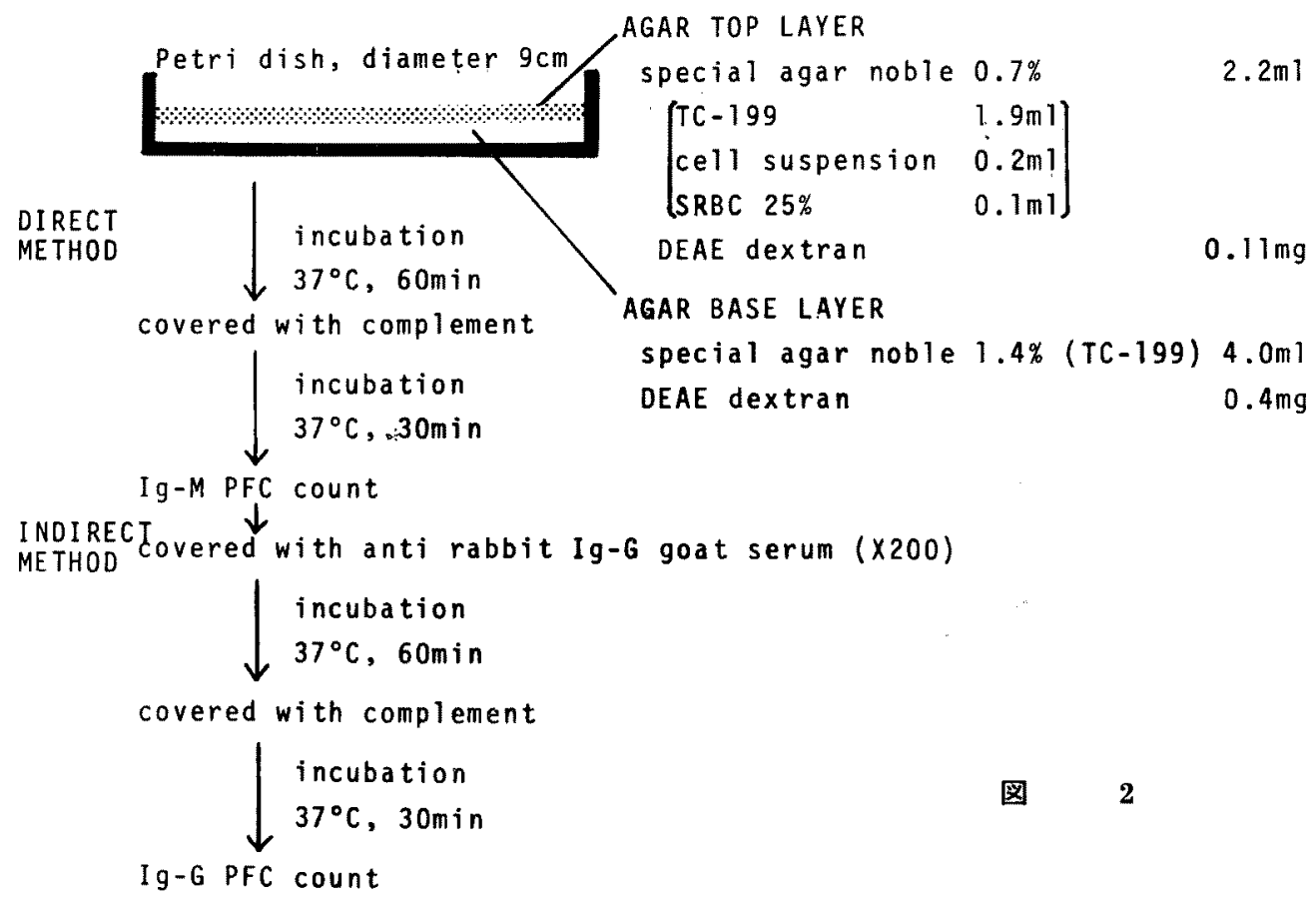


(iii) $\mathrm{CO}_{2} 5 \%, 37^{\circ} \mathrm{C}$, 水蒸気飽和, 細胞培養恒温器で静

重培養. 培養液の交換を行わずに 4 日間培養した後, 抗体産生細胞の検定を行つた. 培養を 4 日間としたのは in vitro における反応が一般に 4 日目にピークを描くか らである. ${ }^{7) 8 ~}$

\section{7) 細胞浮遊液調整法}

脱血死せしめた感作家兔の扁桃, 頸部リンパ節（靧下 部, 頚動静脈周辺部), 脾臟 および非感作家鬼脾臟をな る心゙く無菌的に摘出し, 培養液中で良く洗い周囲の結合 織, 脂肪組織を除去した後, 注射針を使つて細胞を培養 液中に遊出させる. 小さな細胞塊は顕微鏡用カバーグラ スにはさんで軽く圧して細胞を遊出させる. 白金メッシ _. (No. 150) で濾過し, 可及的均一な細胞分画を得, 800r.p.m., 10min. の遠沈で細胞を洗い再び同 Eagle, MEM に浮遊させる. $0.1 \%$ crystal violet 加 $0.1 \mathrm{M}$ ク エン酸水溶液で有核細胞数を計測し $10 \times 10^{6} / \mathrm{ml}$ となる ように調整した。

混合培養群では前述の組合せに感作細胞, 非感作細胞

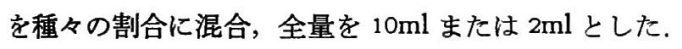

\section{8）培養細胞の採取}

各シャーレより細胞浮遊液を採取 (この際ガラス面に 付着した細胞は，ゴムハケを使つて剝がした）800r.p.m., $10 \mathrm{~min}$. の遠沈で細胞を集め, Hanks 液で $1 \mathrm{ml}$ に再浮遊 しこれを原液として以下10倍，100 倍，1000 倍の稀釈 浮遊液を作り, 各々の $0.2 \mathrm{ml}$ を Jerne の hemolytic plaque technique に用いた. 同時に採取時の細胞数を算 定, 培養開始時の細胞数と比較し, PFCの換算に用い た. なお, 生細胞の確認には $0.5 \%$ trypan blue を使用 した.

\section{9) 抗体産生細胞 (PFC) の測定}

図 2 の如くJerne の hemolytic plaque technique を 多少 modify し plaque forming cell, PFC を測定し た. ${ }^{836) 93}$

上記細胞浮遊液 $0.2 \mathrm{ml}$ と， $25 \% \mathrm{SRBC} 0.1 \mathrm{ml}$ を加え た0.7\% 199寒天培地 $2.2 \mathrm{ml}$ を, あらがめ $4 \mathrm{ml} の 1.4 \%$ 199 寒天培地の base layer をしいてある直径 $9 \mathrm{~cm}$ のプ ラスチック Petri dish に流して重層する.これを $37^{\circ} \mathrm{C}$ で60分間睬卵器に入れた後, 補体 (東芝化学K.K. 製乾 燥補体) 10倍稀釈 Hanks 液を充分（1シャーレに約 2 $\mathrm{ml}$ ) 加え, さらに $37^{\circ} \mathrm{C} 30$ 分睬卵器に入れ, 現われた溶 血斑を数えて, IgM-PFC 数とした.

次に抗ウサギ IgG ヤギ血清（教室の鈴木作製による） の200 倍稀䣋液を $2 \mathrm{ml}$ す゚つ各シャーレに加えて, $37^{\circ} \mathrm{C}$

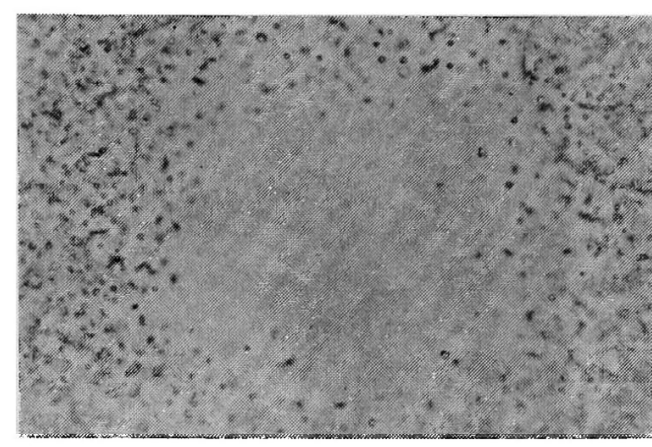

写真 1 溶血斑の拡大, 中央に形質細胞様細胞 を認める。

60分間畔卵器に入れ, 前回と同様に補体を加えて 30 分後 現われた溶血斑を数え, これと IgM-PFC との差をもつ て IgG-PFC とした. (写真 1) plaque の中央には形質 細胞様の細胞が同定される. Hannoun et al. ${ }^{10)}$ は同時 に細網細胞様細胞やマクロファージ様細胞もみられる が，これらは本質的に形質細胞と同じものであろらと述 ベている.

10）混合培養群における PFC の換算比較法

混合培䖯群においては感作細胞と非感作細胞が種々の 割合に混じているので, 次のような換算式を用い比較す ることにした.

\begin{tabular}{|c|c|c|c|}
\hline \multirow{2}{*}{\multicolumn{2}{|c|}{$\begin{array}{c}\text { 培養開始時 } \\
\text { 細胞数 }\end{array}$}} & 採取時 & PFC の数 \\
\hline & & 和肥榇 & PFCo \\
\hline 混合培養群 & $\mathrm{Nm}$ & $\mathrm{N}^{\prime} \mathrm{m}$ & $\mathrm{PFCm}$ \\
\hline & (感作細胞感作組 & $\left(a^{\prime}+b^{\prime}\right.$ & \\
\hline
\end{tabular}

とすると，

単独培養群の単位細胞数当たりの PFC は

PFCs

混合培養群の単位細胞数当たりの $\mathrm{PFC}$ は

$\frac{\mathrm{PFCm}}{\mathrm{N}^{\prime} \mathrm{m}}$

(2)を混合したもとの感作細胞当たりの PFC に換算する と

$$
\frac{\mathrm{PFCm}}{\mathrm{N}^{\prime} \mathrm{m}\left(\frac{\mathrm{a}^{\prime}}{\mathrm{a}^{\prime}+\mathrm{b}^{\prime}}\right)}
$$

混合培養に扔ける感作細胞数 $\mathrm{a}$ と非感作細胞数 $\mathrm{b}$ との混 合比が探取時にも変わらないものと仮定して, すなわち $\mathrm{a}: \mathrm{b}=\mathrm{a}^{\prime}: \mathrm{b}^{\prime}$ として 
(3) $=\frac{\text { PFCm }}{N^{\prime} m\left(\frac{a}{a+b}\right)}$

$\frac{(4)}{(1)} \times 100$ をむつて増加率とした.

なお，いずれの場合もまず background PFC として Control の PFC を減じてある.

Single Culture においては $\mathrm{PFC} / 10^{6}$ は当該細胞群の 抗体産生細胞数をそのまま表わしているわけであるが， Mixed Culture においては換算值であるので，実際観察 される PFC ではなく, 当該細胞群のみから PFC が出 現したと仮定した場合の単位細胞数当たりの抗体産生細 胞数ということになる。 また逆に，上述の如く換算した PFC の増加分が非感作脾細胞単位細胞当たり何個かと いうことを $\{(4)-(1)\} \times \frac{\text { 感作細胞数 }}{\text { 感作脾細胞数 }}$ の式により換算 して検討しても, 同一の傾向が得られたので，以後は前 述の換算法を用いた結果を使用した. したがつてこの数 值加は増加の絶対数は求められす，各々の場合の増加 または減少傾向を知ることになる。

\section{実験結果}

1 ）培養細胞数の減少

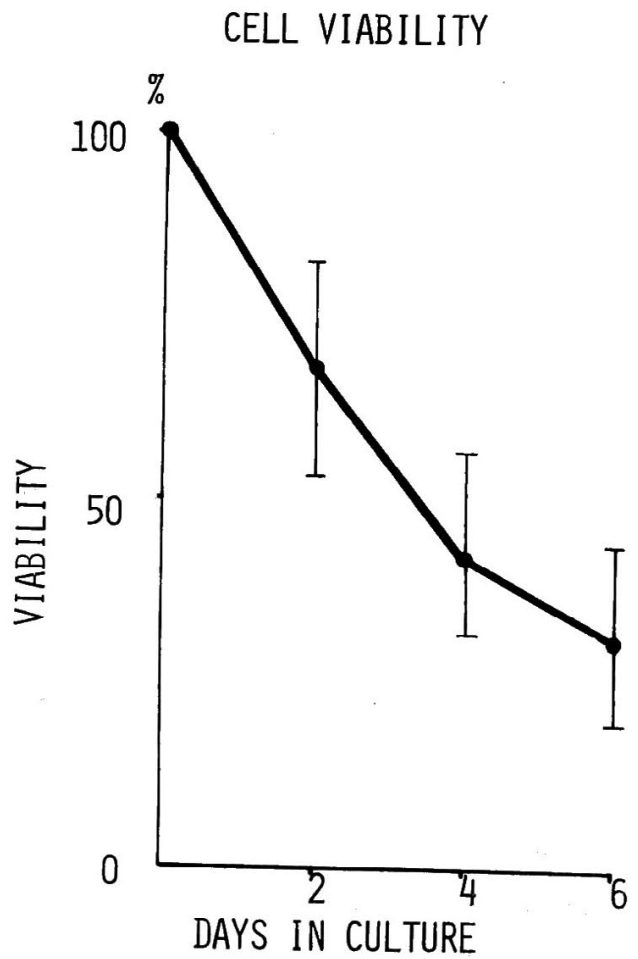

図 3

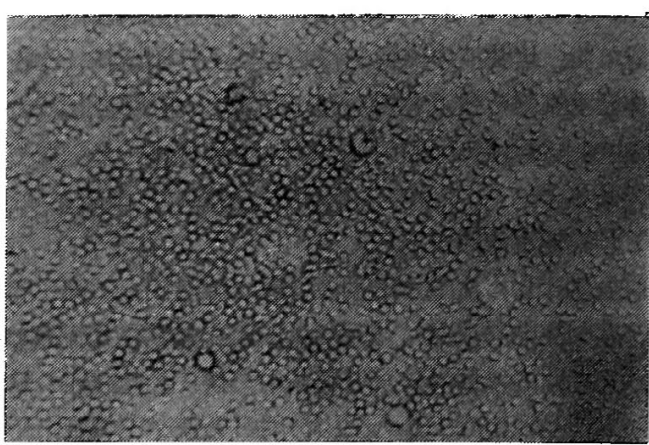

写真 2 扁桃細胞, 培養 4 日目

TITER \& TOTAL DOSE OF 25\% SRBC

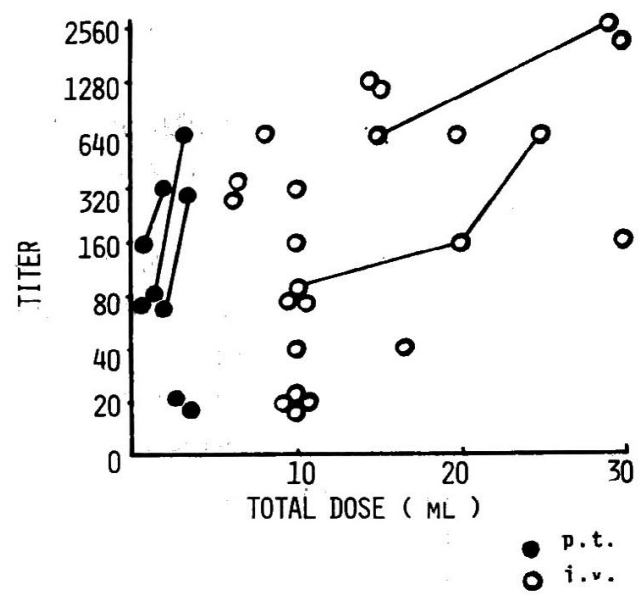

TITER \& TIMES OF SENSITIZATION

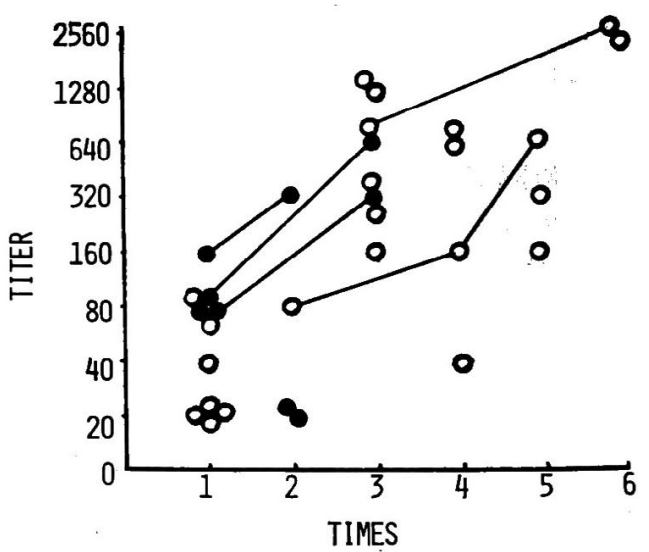

图 4 


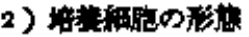

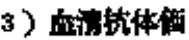

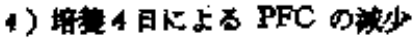

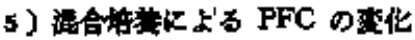

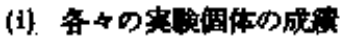

(4i) 全体の㮌向

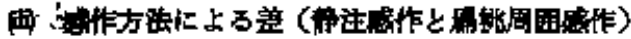

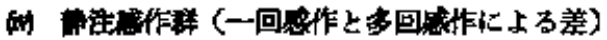

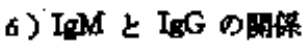

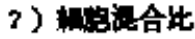

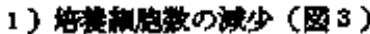

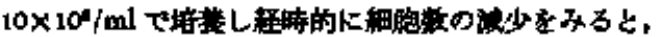

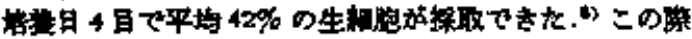

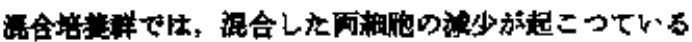

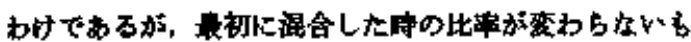
のと仅定した。

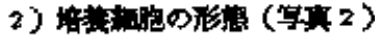

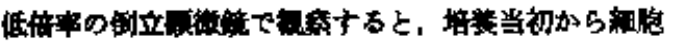

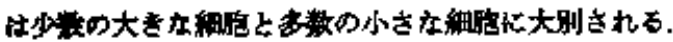

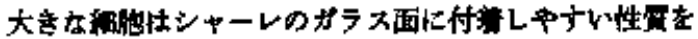

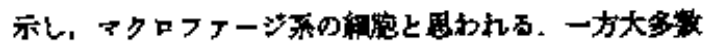

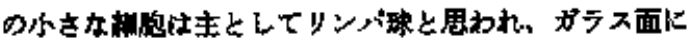

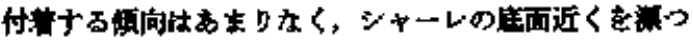
ている上うに胃られる。

\section{3) 血游㧧体侮 (图4)}

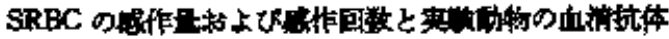

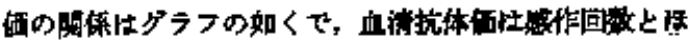

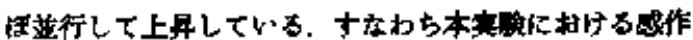

表 1 Rabbit No, 20 (207)

sensitization 25\%SRBC $5 \mathrm{ml} \times 4$ times

\begin{tabular}{llrr|c}
\hline PFC $/ 10^{\circ}$ & $\begin{array}{l}\text { At } \\
\text { Sarcrifice }\end{array}$ & $\begin{array}{l}\text { After } \\
\text { Culture }\end{array}$ & RATIO\% \\
\hline \multirow{2}{*}{ Splese } & Ig-M & 469.92 & 60.00 & 13 \\
& Ig-G & 61.55 & 31.13 & 51 \\
\hline \multirow{2}{*}{ Lymphnode } & Ig-M & 13.52 & 1.39 & 10 \\
& Ig-G & 4.60 & 0.68 & 19 \\
\hline \multirow{2}{*}{ Control } & Ig-M & 3.64 & 0.34 & 9 \\
& IgG & 2.27 & 0.35 & 11
\end{tabular}

2

EXPER]MEYFN RESUI I PFC MHEER / 10,

\begin{tabular}{|c|c|c|c|c|c|c|c|c|c|c|c|c|c|c|c|}
\hline \multirow{3}{*}{$\begin{array}{c}\text { ndett } \\
\text { mo. }\end{array}$} & \multirow{2}{*}{\multicolumn{2}{|c|}{ sEnsity }} & \multirow{3}{*}{ TITEN } & \multicolumn{4}{|c|}{ TOISIL } & \multicolumn{4}{|c|}{ SPLF" } & \multicolumn{4}{|c|}{ 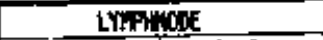 } \\
\hline & & & & Ig-P & & 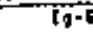 & & $19=$ & & $I_{9}-$ & & $\mid \overline{14-1}$ & & 19- & \\
\hline & 1.7. & p.t. & & SIHCLE & MI $X \mathrm{EO}$ & SI IALE & MIKED & SIMELE & atxeD & S1MgLE & MIXEO? & 5I Wate & MIXEA? & SI IOLLE & W5MED \\
\hline $1(109)$ & 10גו & & 20 & & 0.15 & & 1.13 & & 3,60 & & 0.36 & & +.03 & & 1,65 \\
\hline 2 [נו2] & soin & & 80 & 7.60 & 2.00 & 10.63 & 1.00 & 0.45 & 0.73 & 2.21 & 0,79 & 1,78 & 0.97 & 0.67 & ו1.5 \\
\hline $3|113|$ & $10 \times 1$ & & 20 & 4.00 & 9.45 & 3.60 & 6,25 & 1.52 & 4.11 & 3.43 & 6.24 & 27.71 & 5.93 & 5.60 & 1.05 \\
\hline $4(1) 4)$ & $10 \times 1$ & & 20 & & & & & 4.97 & 5.43 & 1.44 & 0.55 & 1,91 & 2,34 & 1.86 & 0.80 \\
\hline 5 (115) & 10x & & 20 & 0.64 & 11.72 & 0.22 & 5,74 & 90.56 & 12.48 & 25.00 & 9.1. & 1.95 & 0.29. & 7.32 & $3,65$. \\
\hline 6 (116) & $\log _{3 x 3}$ & & 10 & 4.17 & 1.79 & 0.00 & 1,90 & 3.43 & 0.93 & 3,41 & D.As & 0.25 & 1.12 & 0.08 & 0.56 \\
\hline$T(11)\}$ & $2 \pi 3$ & & 320 & 0.63 & 3.87 & 0.16 & 9.76 & & 122.77 & 70.71 & $16 \$ .30 !$ & 6.28 & 7.14 & 2.46 & 3.64 \\
\hline (11a) & $2 \times 5$ & - & 320 & 0.56 & 15.05 & a. 56 & 2.27 & 70.25 & 15.63 & 12.40 & 7.731 & 2.11 & $14+39$ & 5.43 & 10.6 \\
\hline $9(119)$ & $2 \times 5$ & & 160 & 0. 56 & 8,82 & 0.58 & 7.04 & 16.23 & 78.05 & 4.82 & 70.49 & 2.31 & 17.43 & 0.75 & 2.15 \\
\hline $30(120)$ & $2 \times 3$ & & 320 & 0.71 & 0.75 & 1.79 & $2+38$ & 30.92 & 25.35 & 6. & 47.48 & 1.06 & 12.41 & $2+11$ & 3.87 \\
\hline ts $(12 \pi)$ & $2 \pi 4$ & & 540 & 6.67 & & 3.33 & & 20.00 & 10.11 & 19.70 & | & 1,45 & 13.45 & 1.08 & 7,52 \\
\hline $12\langle 123\}$ & $5 \times 3$ & & 12800 & $14.2 \mathrm{~g}$ & 1.49 & 0.00 & 1.46] & 31.67 & 56,50 & 1.48 & 11.50| & 3.43 & 5,600 & 5.31 & 3.99 \\
\hline 17 (325) & $5 \times 3$ & & 1280 & 3.30 & 0.00 & 12.50 & 0.00 & 7,14 & 15.56 & 4,20 & 6.92 & 0.00 & 2.37 & 0.30 & 1.15 \\
\hline $14(126)$ & $5 \times 6$ & & 25100 & 0.00 & 1.4. & 1,25 & 1.81 & 10.00 & 14. $\mathrm{BA}$ & 20.77 & 26.56 & 0.25 & 0.00 & 1,75 & 1.50 \\
\hline $15(127)$ & sxe & & 2560 & 2,00 & 0.00 & 0.00 & 0.00 & 7.50 & $13,68$. & 37.50 & 137,90 & 4. 56 & 0.00 & 3.33 & o, ac \\
\hline $16(128)$ & $5 \times 5$ & & 640 & $0+\infty$ & 0.00 & 0.00 & 0.28 & 10.40 & 4.30 & 67.05 & 50.56 & 0.79 & 0.14 & 2.91 & 3.60 \\
\hline $17[124]$ & $10 \times 1$ & & 10 & a. 22 & 0.17 & 0.67 & 0.27 & 0.44 & 2.19 & 0.04 & 0.81 & 0.67 & 0.00 & 0.32 & 0.17 \\
\hline 14 (zas) & $\operatorname{lox} 1$ & & at & 0.08 & 0,00 ? & 0.00 & 1,50: & 6.12 & 0.42 & 4.08 & 1.26 & 3.65 & 2.96 & 9.27 & 2.00 \\
\hline is (200) & $10 \times 3$ & & 160 & & & & & 0.93 & $0+96$ & 2.34 & 1.90 & 1.54 & 0.56 & 0.00 & 2.76 \\
\hline $20(207)$ & $6 \times 1$ & & 640 & 0.00 & 2,33 & 0.26 & i.til & 60.00 & 40.56 & 31,11 & 7059 & 1.39 & 1.21 & 0.69 & 1.21 \\
\hline $21(122)$ & $2 \times 1$ & $1 \times 1$ & 20 & 0.00 & 0.00 & 0.00 & 0.40 & 2.96 & 9.61 & 1.04 & 2.90 & 11.74 & 26.69 & 3.92 & 6.74 \\
\hline $22(124)$ & $2 \times 1$ & 1t: & 20 & 0.100 & .7 .50 & 0.00 & 1,94 & 5,32 & 7.86 & 0.32 & 2,67 & 0.78 & 16.08 & 0.22 & 0.33 \\
\hline $23(201)$ & & $1 \times 2$ & 320 & $0+10$ & 0.00 & 3.33 & 2.15 & 0.43 & 0.00 & 4.70 & 16.64 & 0.93 & 0.16 & 10. 18 & 32.82 \\
\hline $24(20 z)$ & & 183 & $\$ 40$ & 0.00 & 0.00 & 0.00 & $0,00^{3}$ & 0.21 & 1.00 & 1,40 & 1.10 & 0.09 & D.29 & 3,36 & 1.24 \\
\hline
\end{tabular}

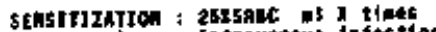

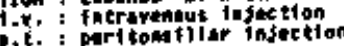

Fiten seras antibedy titur ( hawaglutinetion) 

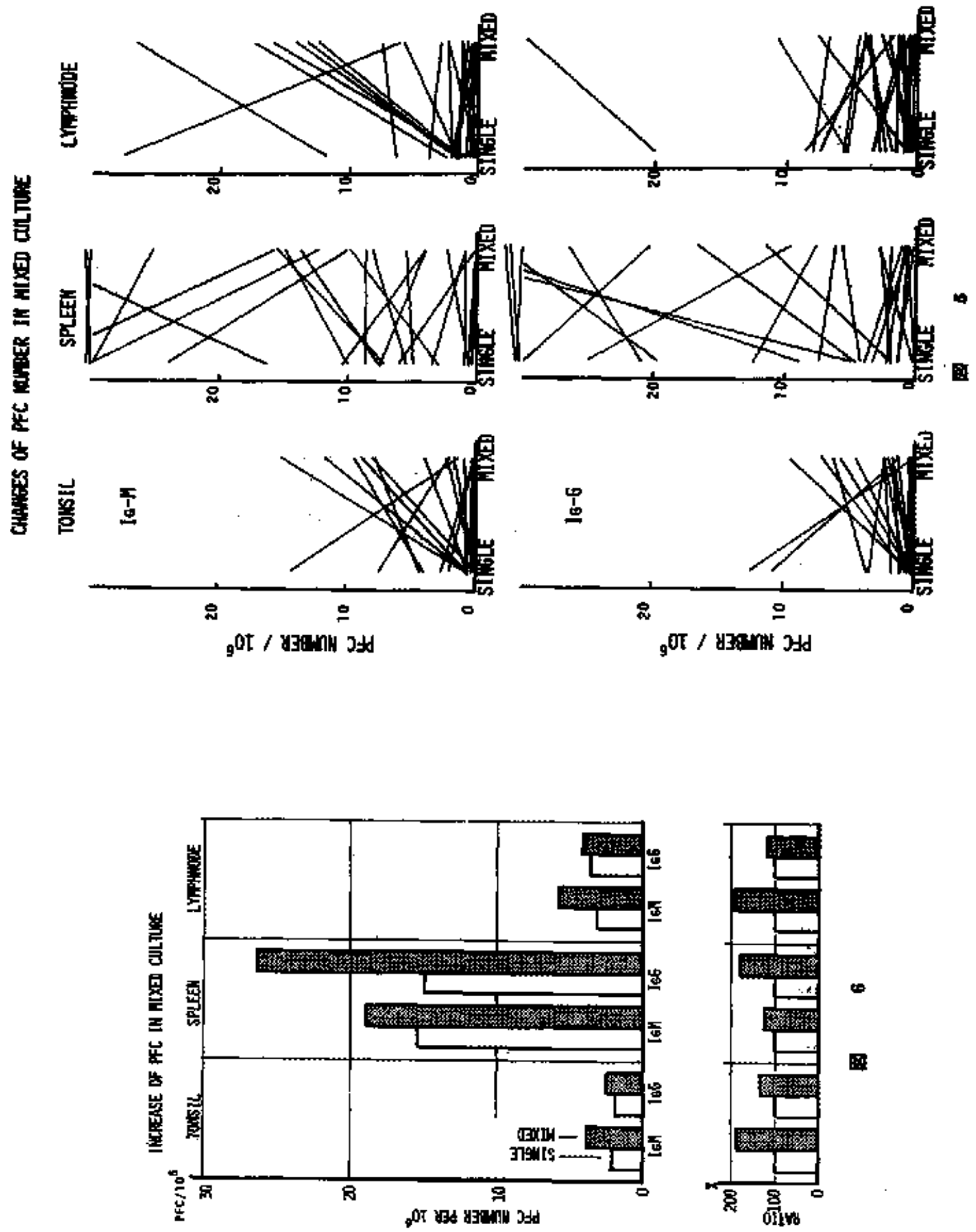
条件では, 血清抗体価住 SRBC の感作総量の增加によ るよりは，感作回数を增やすことにより上昇することが わかる。

\section{4) 培美 4 日によるPFC の減少（表 1)}

感作動物の培羕細胞の PFC 出現は培養 4 日閒で $1 / 2 \sim$ $1 / 10$ に減少した。 また表に明らかなようにIgM-PFC の減 少にくらべて IgG-PFC の減少が少ないのは，免疫学的 記檍と関保があるるのと思われる。

5) 混合培養による PFC の変化

(i) 各々の実験個の成績（表 2，図 5)

各感作組織単独培新による 単位細胞数当たりのPFC と，実験方法10)で示した計算式にしたがつて換算した 混合培美による単位細胞数当たりの PFC を対比してま とめた。

混合培盖による堌加分は, 感作臟器に存在していた SRBC に対する抗原認識細胞 antigen reactive cell, ARC 加非感作脾臟の抗体産生前麃細胞 antibody forming cell-precursor, AFC-P と反応して抗体産生細胞 antibody forming cell, AFC の增加をもたらし, plaque として 出現したものと考えられる。しかし混合培垱群の值が単

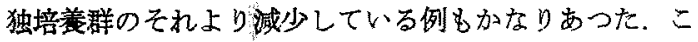
の PFC の增加と減少が何を意咮するかについては後述 する.

また少数例ではあるが特に扁桃におるて，単独培養群 で PFC の出現をみないのに, 混合培佂群で PFC を観 察したものや，両群ともに PFC の出現を見なかった例 （扁桃周围感作群汇多い）があつた。

後の考按で述べるように，混合培㚜による PFC の增 加，减少の意義づけは難しく，一概に論ずることはでき ない，したがって個々の症例についての解釈は困難とな り，数を重ねてその傾向を知る他はない，そこで平均を とつていくつかの項目について検討してみた.

(ii) 全体の傾向（表 3 , 図6）（RABBIT No. 1 No.

表 3 Mean

\begin{tabular}{llcc|c}
\hline \multicolumn{2}{c}{ PFC/10 } & Single & Mixed & RATIO\% \\
\hline \multirow{2}{*}{ Tonsil } & Ig-M & 2.12 & 3.88 & 183 \\
& Ig-G & 1.86 & 2.50 & 133 \\
\hline \multirow{2}{*}{ Spleen } & Ig-M & 15.43 & 18.90 & 122 \\
& Ig-G & 14.85 & 26.32 & 177 \\
\hline \multirow{2}{*}{ Lymphnode } & Ig-M & 3.06 & 5.68 & 186 \\
& Ig-G & 3.56 & 4.14 & 116
\end{tabular}

表 4 Intravenous (i.v.) and Peritonsillar (p.t.) Sensitization

\begin{tabular}{|c|c|c|c|c|c|}
\hline $\begin{array}{l}\text { Sensiti- } \\
\text { zation }\end{array}$ & $\mathrm{PFC} / 10^{\circ}$ & & Single & Mixed & RATIO $\%$ \\
\hline \multirow{6}{*}{ i.v. } & \multirow{2}{*}{ Tonsil } & Ig-M & 2.61 & 4.32 & 166 \\
\hline & & Ig-G & 2.10 & 2.83 & 135 \\
\hline & \multirow{2}{*}{ Spleen } & Ig-M & 18.36 & 21.87 & 119 \\
\hline & & Ig-G & 17.54 & 30.46 & 174 \\
\hline & \multirow{2}{*}{ Lymphnode } & Ig.M & 3.00 & 4.65 & 155 \\
\hline & & $\mathrm{Ig}-\mathrm{G}$ & 2.65 & 2.91 & 110 \\
\hline \multirow{6}{*}{ p.t. } & \multirow{2}{*}{ Tonsil } & Ig-M & 0.00 & 1.98 & $\infty$ \\
\hline & & Ig-G & 0.83 & 1. 13 & 136 \\
\hline & \multirow{2}{*}{ Spleen } & Ig-M & 2.23 & 4.37 & 196 \\
\hline & & Ig-G & 2.07 & 5.60 & 271 \\
\hline & \multirow{2}{*}{ Lymphnode } & Ig-M & 3.36 & 10.80 & 321 \\
\hline & & $\mathrm{Ig} \cdot \mathrm{G}$ & 7.85 & 10.28 & 131 \\
\hline
\end{tabular}

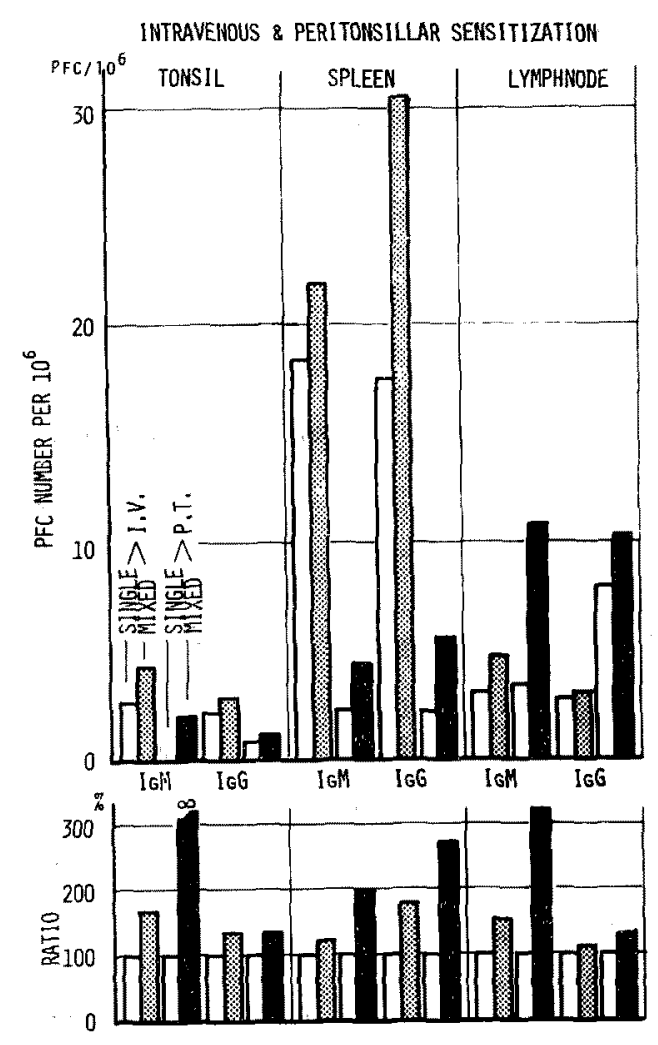

图 7 
24)

扇桃，脾藏，リンパ節ともに単独群にくらべて混合培 羕群の方が IgM, IgGのいずれも増加している．増加率 Ratio は単独群を100とした時の割合を表わしたもので ある. PFC の絶対数は脾臟で一番多く、リンパ節では 脾臟の約 $1 / 5$ と低值を示し，扁桃はさらに低值を示す，增 加率は扁桃の IgM, リンパ節の IgM ともに高く，廨 桃・リンパ節は良く似たパターンを示している.

(iii) 感作方法による差（静注感作と扁桃周囲感作）（表 4, 図 7)

静注感作 i.v. (RABBIT No. 1-No. 20) では, PFC の絶対数はやはり脾荗に多く，扁挑とリンパ節では絶対 数，率ともに似たよらな態度をとつている。これに対し て扇桃周囲感作 p.t. (RABBIT No. 21-No. 24) では, 絶対数においては扁桃，脾臟，リンパ節の順に多くな り，特に扁桃のIgM-PFC は単独培荃群では検出でき ず，混合培養群で出現している．したがつて増加率では 扁桃の IgM-PFC は無限大の堌加を示し, 次いでリンパ 節の IgM-PFC となつた。頸部りンパ節を奏験に供して いるのでリンパ節への影響が大きくてるの注うなずけ る、しかし，扁兆実質を通して扁桃周囲人，場合によつ ては扁桃実質内一抗原 SRBC を注射したにも拘らず， 扁桃における PFCの少ないことが注目される。これは SRBC の抗原性や，抗原情報の流れに関俰があるよ5に 思われる，また一回の感作量が限られていること，感作

表 5 Intravenous Sensitization one-time and repeated Injection

\begin{tabular}{|c|c|c|c|c|c|}
\hline $\begin{array}{l}\text { Sensiti- } \\
\text { zation }\end{array}$ & $\mathrm{PFC} / 10^{6}$ & & Single & Mixed & RATIO\% \\
\hline \multirow{6}{*}{$\begin{array}{l}\text { one- } \\
\text { time }\end{array}$} & \multirow{2}{*}{ Tonsil } & Ig-M & 2.47 & 5.27 & 213 \\
\hline & & $\operatorname{Ig}-G$ & 3.06 & 2.75 & 68 \\
\hline & \multirow{2}{*}{ Spleen } & Ig-M & 9.68 & 5.28 & 55 \\
\hline & & $I g-G$ & 6.45 & 2.83 & 44 \\
\hline & \multirow{2}{*}{ Lymphnode } & Ig-M & 6.28 & 2.36 & 38 \\
\hline & & $\mathrm{Ig}-\mathrm{G}$ & 3.87 & 2.05 & 53 \\
\hline \multirow{6}{*}{$\begin{array}{l}\text { repeat- } \\
\text { ed }\end{array}$} & \multirow{2}{*}{ Tonsil } & Ig-M & 2.68 & 3.80 & 142 \\
\hline & & $\operatorname{Ig}-G$ & 1.71 & 2.86 & 167 \\
\hline & \multirow{2}{*}{ Spleen } & Ig-M & 22.71 & 30.81 & 136 \\
\hline & & Ig-G & 22.54 & 45.34 & 201 \\
\hline & \multirow{2}{*}{ Lymphnode } & Ig-M & 1.48 & 5.88 & 397 \\
\hline & & Ig.G & 2.09 & 3.37 & 161 \\
\hline
\end{tabular}

回数が少ないこと等も原因しているものと考えられる。 (iv) 静注感作群 (RABBIT No. 1-No，20) 一回感作 one-time Sensitization と多回感作 repeated Sensitization による差（表 5, 図8)

一回感作では, 扇桃 IgM-PFC 以外の全ての PFC は むしろ減少の傾向を示した（単独培養群100に対して混 合培群38～68\%）しかし，扁桃 IgM-PFC のみは增加 傾向 $(21.3 \%)$ を示したことは興味樑い

多回感作では，いずれす混合培養により増加㑯向を示 した．増加率ではリンパ節に IgM-PFC 㧍いて 397\% の 高值を示し，前述扁桃周囲感作に捛ける IgM-PFC 増加 率 $321 \%$ とともにリンパ節の特徴を示すものと考えられ る.

\section{6) $\operatorname{IgM} \Leftarrow \operatorname{IgG}$ の関係}

血清抗体価と IgM, IgG の関係を検討した，各々の症 例で IgM と IgG を比較してす感作条件がそれぞれ異 なるのでこれを IgM>IgG, IgM $=$ IgG, IgM $<$ IgG の

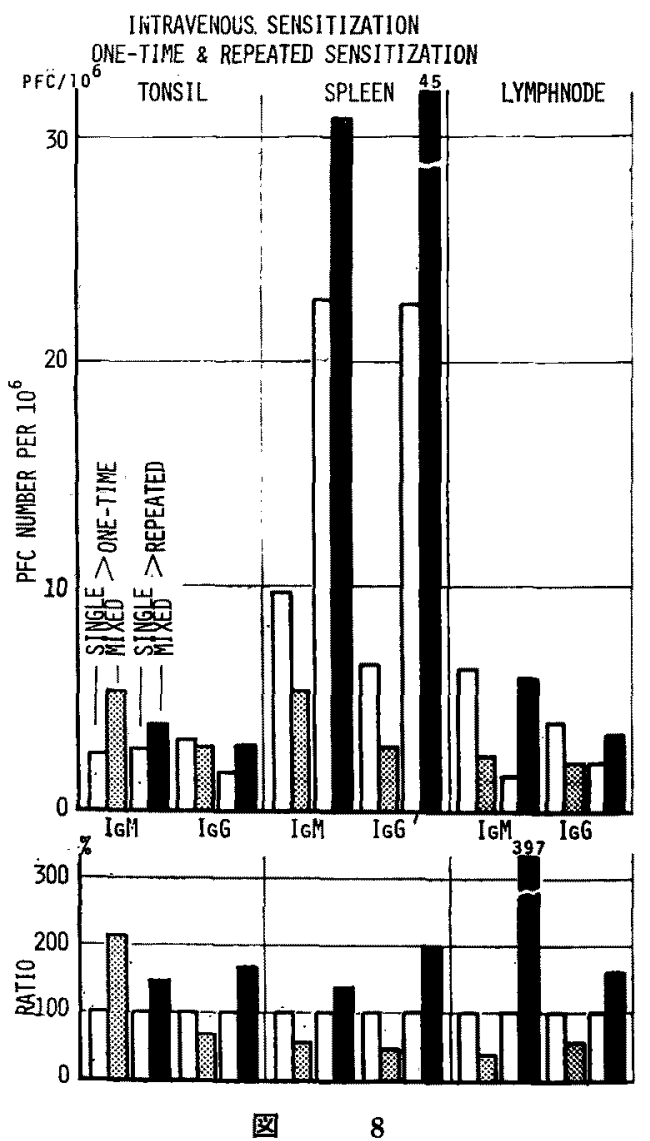


3 群に大別した(図9). 血清抗体価×20では圧倒的に IgM が IgG 上り高值を示す例が多く，血清抗体価が高 くなると IgG の多い例が増え，×2560では IgG の多い 例がほとんど全例安占める。単独培養群でも，混合培養 群でもほぼ感じ傾向を示しているが，混合培養群では低 抗体価の場合も高抗体価の場合も IgM $>$ IgG, IgM $\doteqdot I g G$

表 6 Relation Between Ig-M and Ig-G

\begin{tabular}{|c|c|c|c|c|c|}
\hline & i.v. & Tonsil & en I & node & total \\
\hline . & $\mathrm{Ig}-\mathrm{M}>\operatorname{Ig} \cdot \mathrm{G}$ & 7 & 15 & 12 & 34 \\
\hline one- & $\operatorname{Ig}-\mathrm{M} \fallingdotseq \mathrm{Ig}-\mathrm{G}$ & 3 & 0 & 0 & 3 \\
\hline$\therefore$ & Ig-M $<$ Ig-G & 4 & 2 & 5 & 11 \\
\hline & Ig-M $>$ Ig $-G$ & 10 & 13 & 13 & 36 \\
\hline repeat- & $\mathrm{Ig}-\mathrm{M} \fallingdotseq \mathrm{Ig} \cdot \mathrm{G}$ & 8 & 0 & 1 & 9 \\
\hline & Ig-M $<$ Ig-G & 10 & 16 & 16 & 42 \\
\hline
\end{tabular}

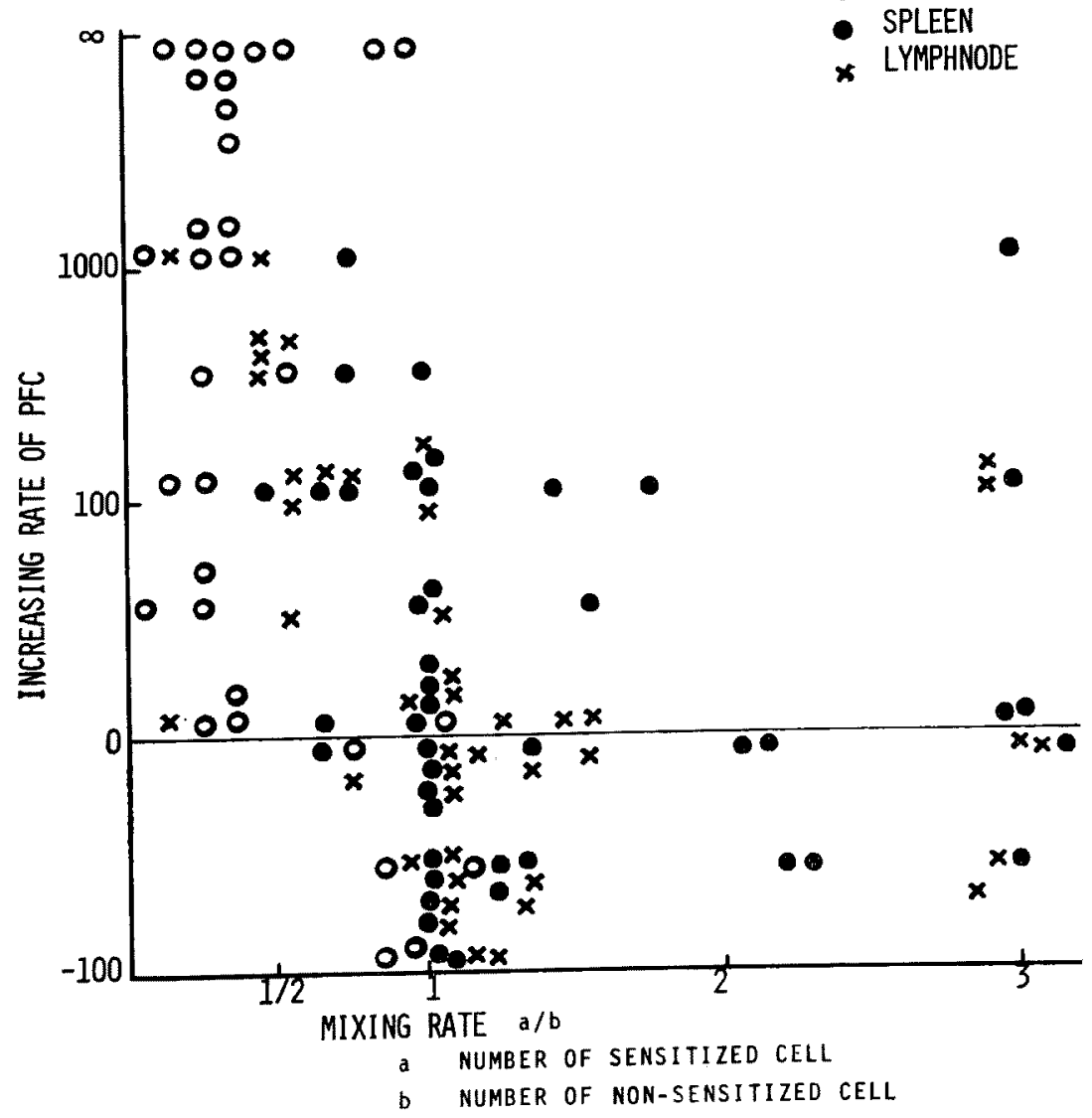

图

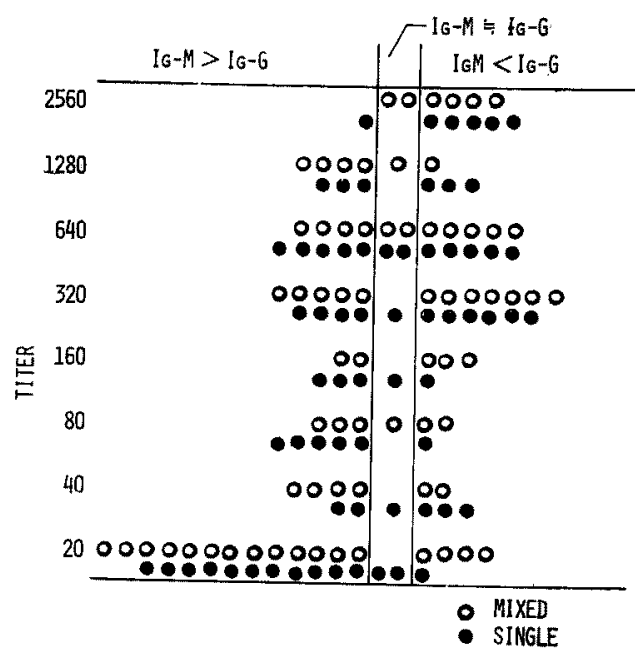

图 9

- TONSIL

SPLEEN

LYMPHNODE 
IgM<IgG.のいずれの舴にむばらつく棈向がみられる。

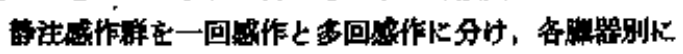

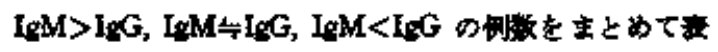

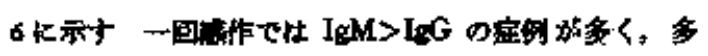

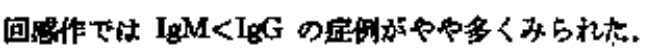

7) 粗胸混合比 (图10)

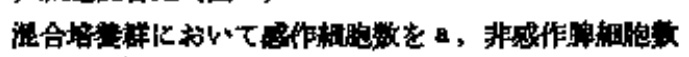

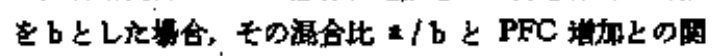

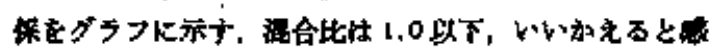

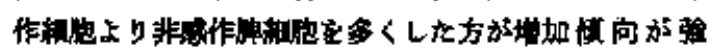

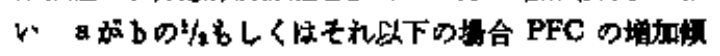

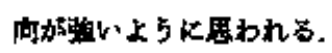

\section{औ 拢}

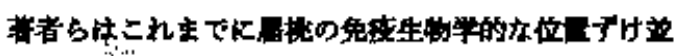

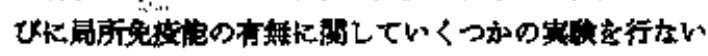

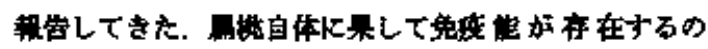

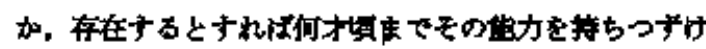

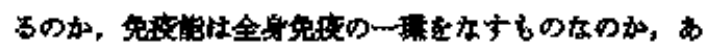

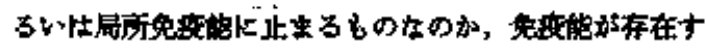

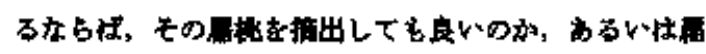

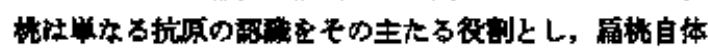

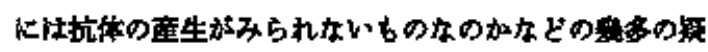

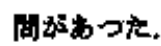

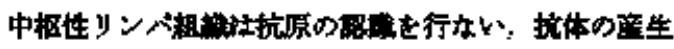

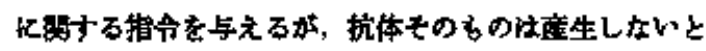

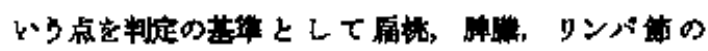

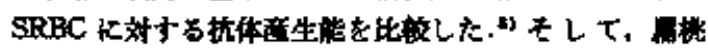

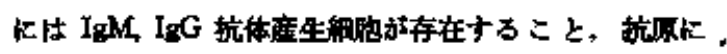

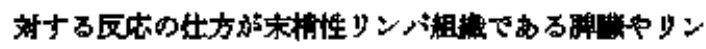

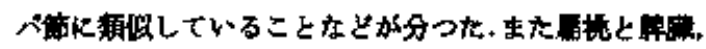

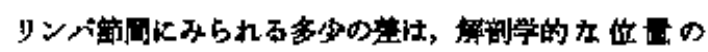
童，十なから外界と国接接しているか否かによるるのと

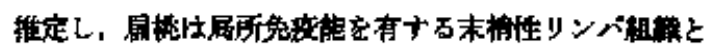
位主サけし。

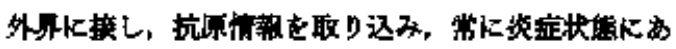

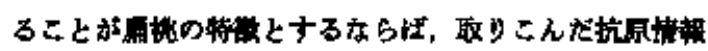

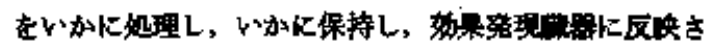

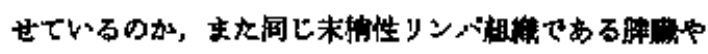

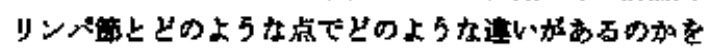

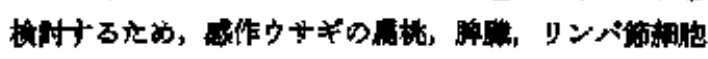

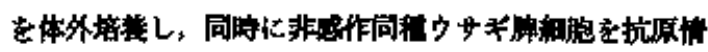

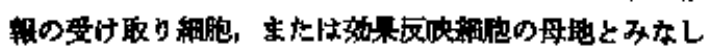

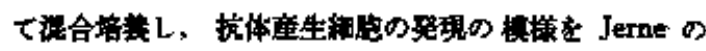

hemolytic plaque techmique

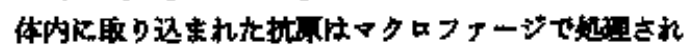

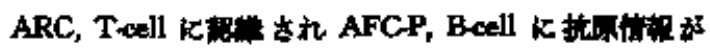

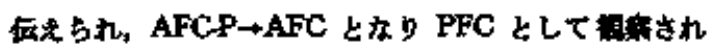

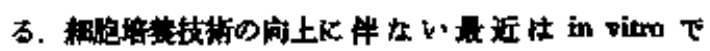
ecoondary responso

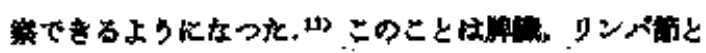

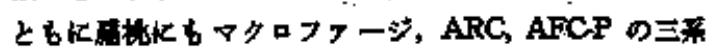
加存在しているととを高来する。

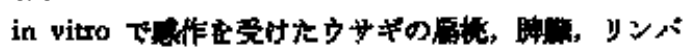

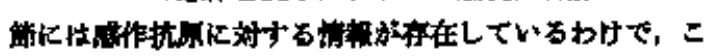

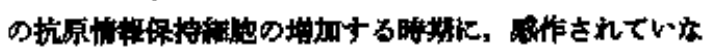
いウサキの AFC.P を如えてやれ标 AFCP $\rightarrow$ AFC (PF

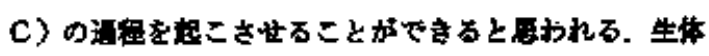

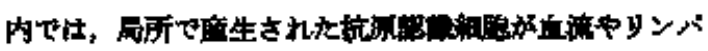

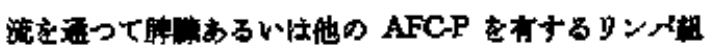

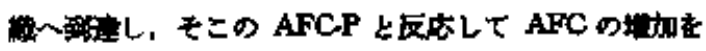

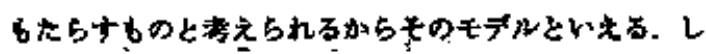
加 L Mishell et ales

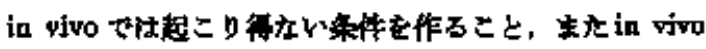
に拈けるような regulating ayotem が店いととなとか

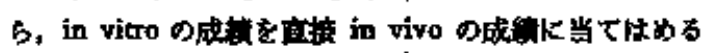
ことはできない

㭧船スケジ

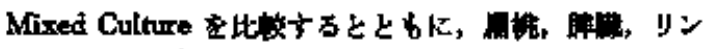

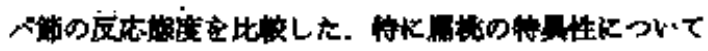

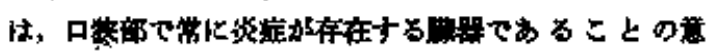

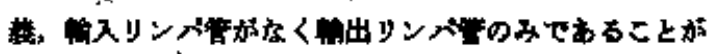

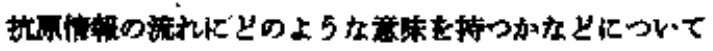
梌时した。

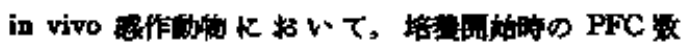

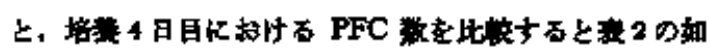

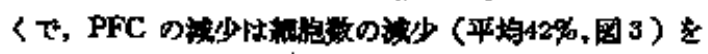

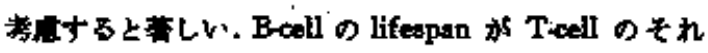

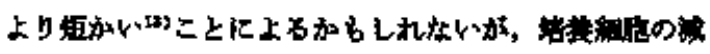

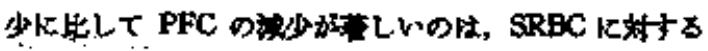

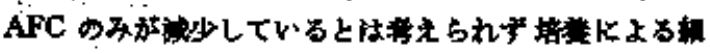

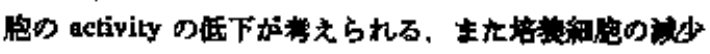

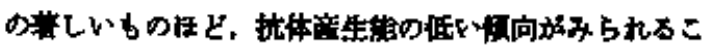

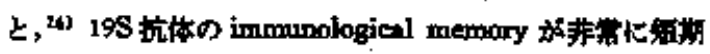

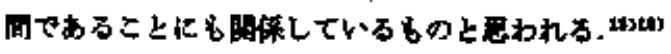

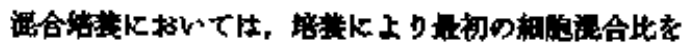

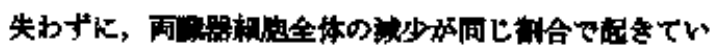




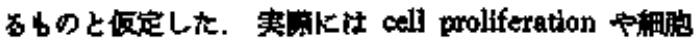

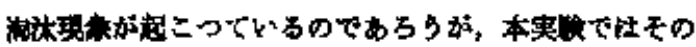

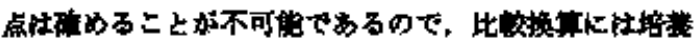

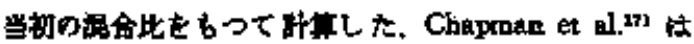

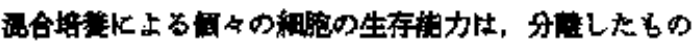
と茟わないと述いている。

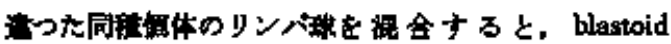
formation が起こることは以前より知られている、10316

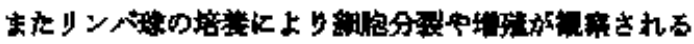

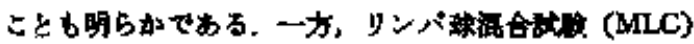

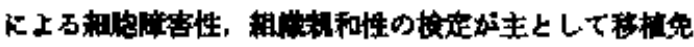

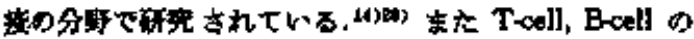

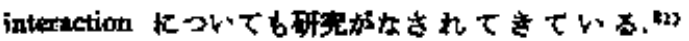

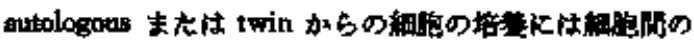

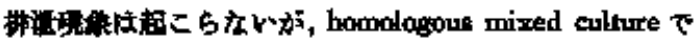

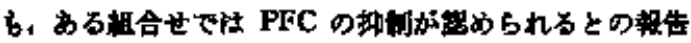

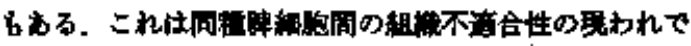

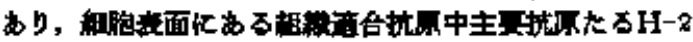

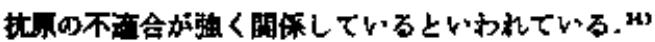

しかし. Mixed Culture $に よ る$ blastoid formation $上$

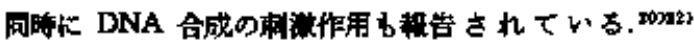

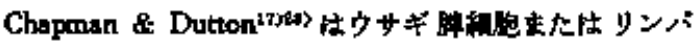

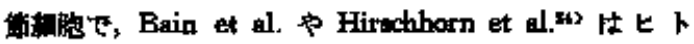

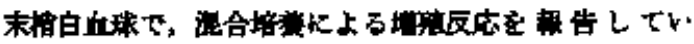
万.

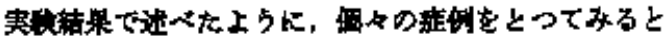

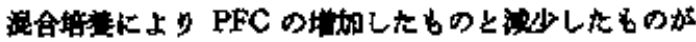

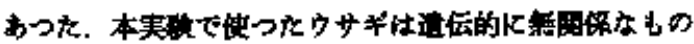

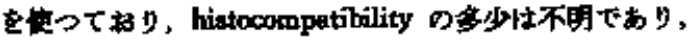

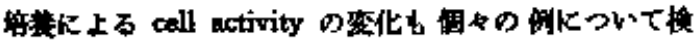
村することはでさない.

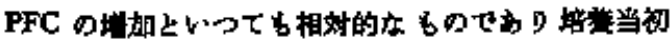

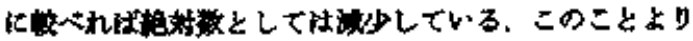

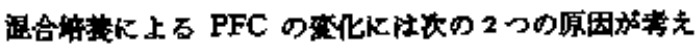
shb.

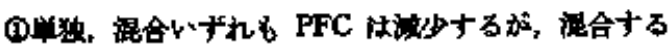

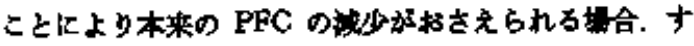

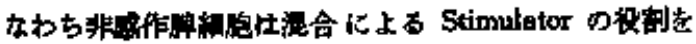

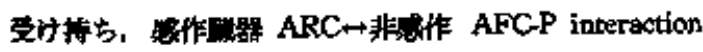
江教充い

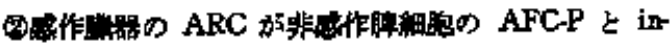

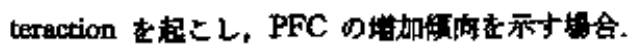

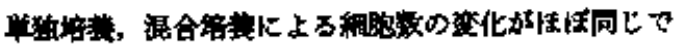

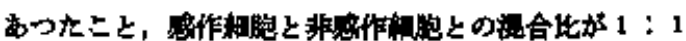

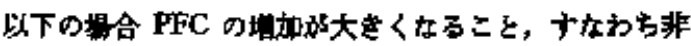

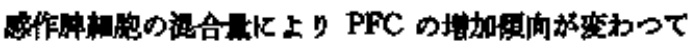

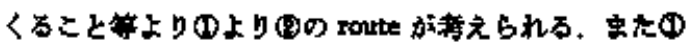

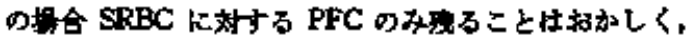

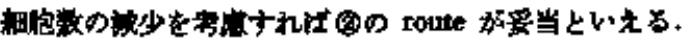

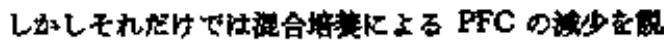

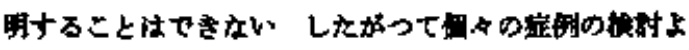

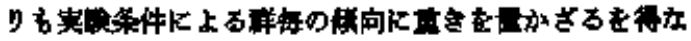
w.

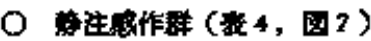

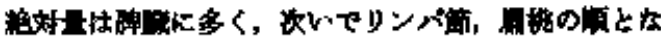

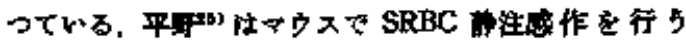

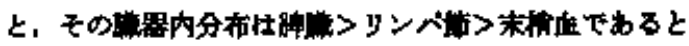
述へている。

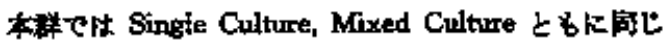

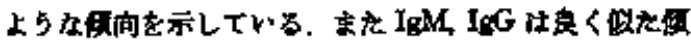

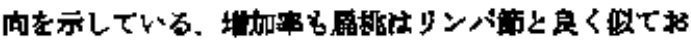

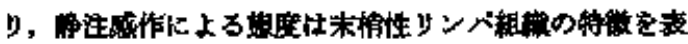

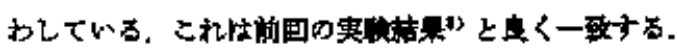

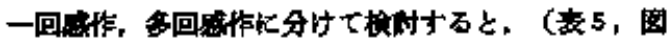

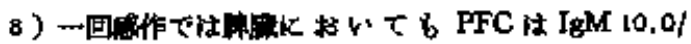

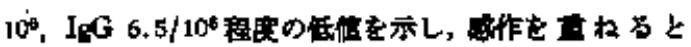

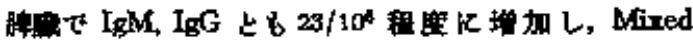

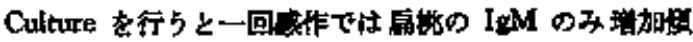
向を示すの忙対し优仕全てむしふ䏚を示した。 このこ

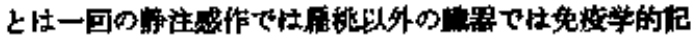

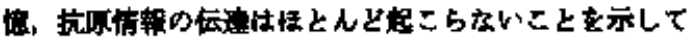

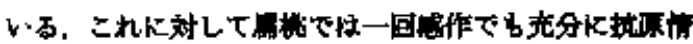

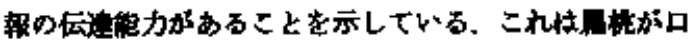

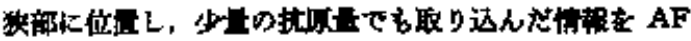

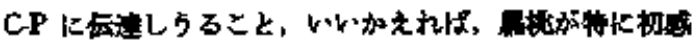

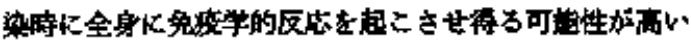
こと意味しているとい兄る。

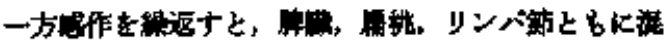

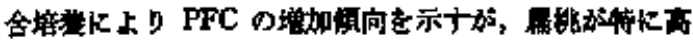

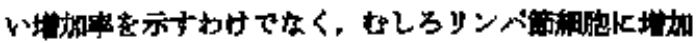

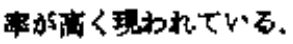

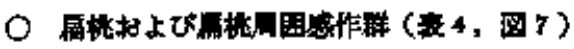

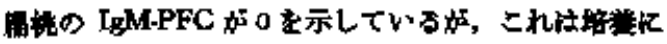
上万 activity の低下化上る 6のと思力れる. Mixed

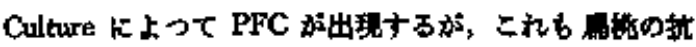

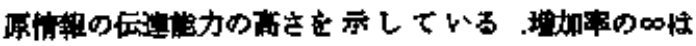




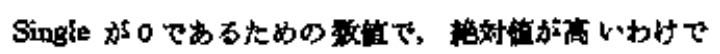

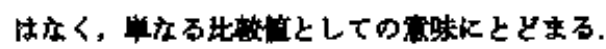

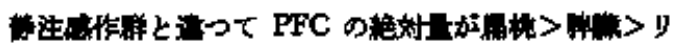

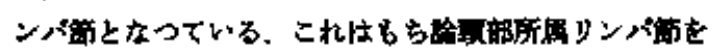

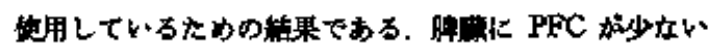

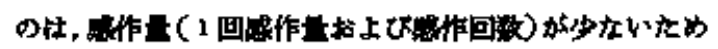

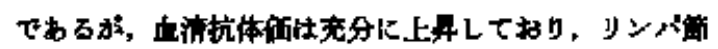

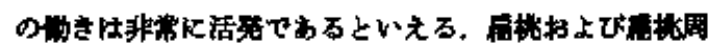

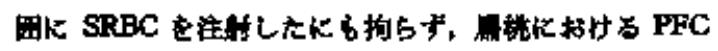

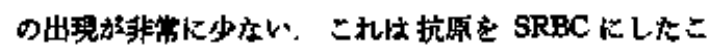

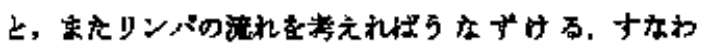

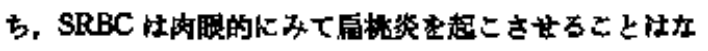

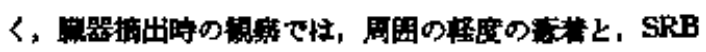

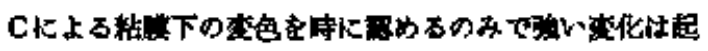

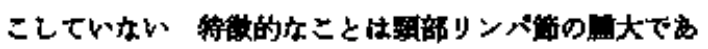

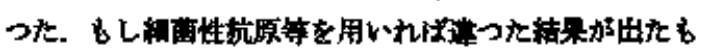

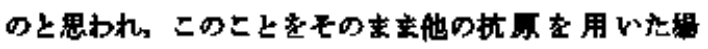

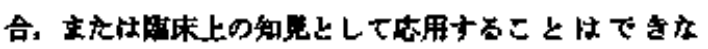

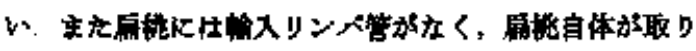

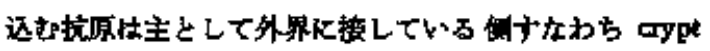

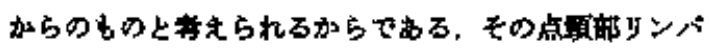

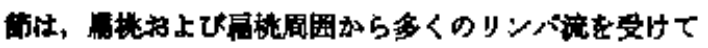
居応しているものと考えられる。

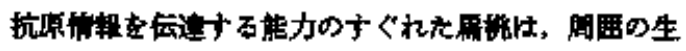
体内加ら抗原を受け万上りる cryptを通して受け取つた

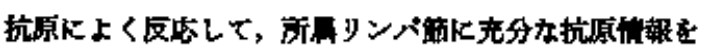

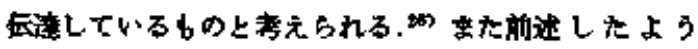

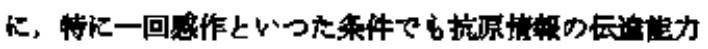

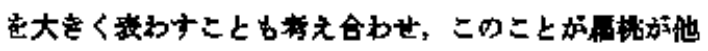

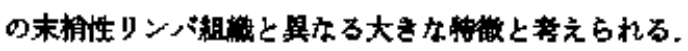

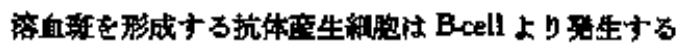
といわれて挌り，その增营を同简しているといわれる

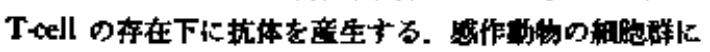

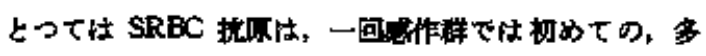

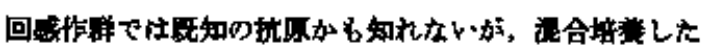

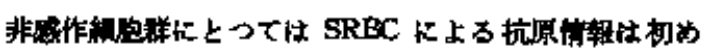

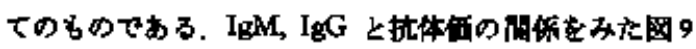

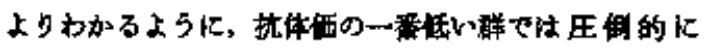

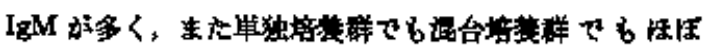

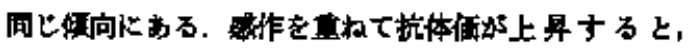

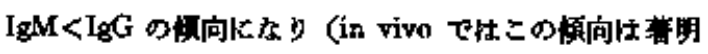

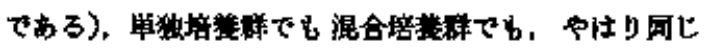

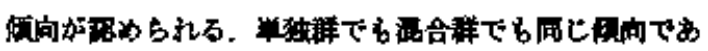

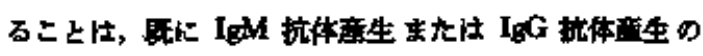

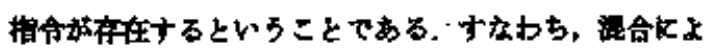

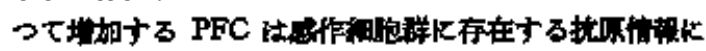

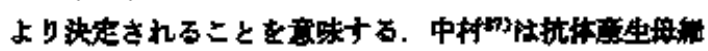

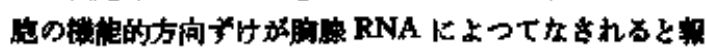

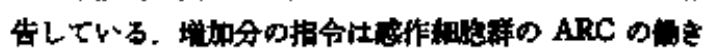
によるということにかると、ARC のま多や，活推いか

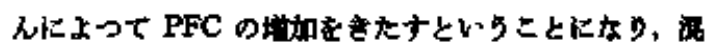

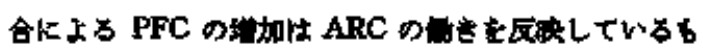
のといえ元.

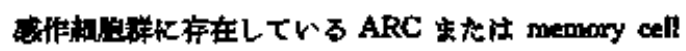

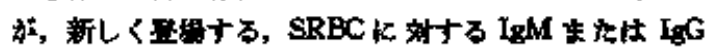

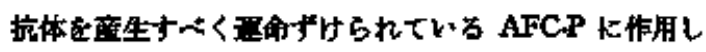

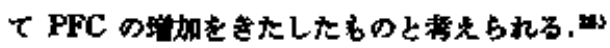

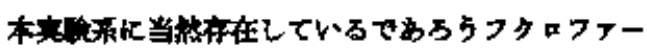

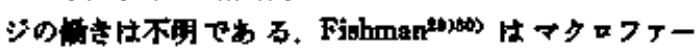

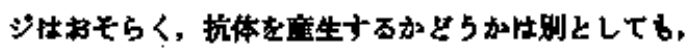

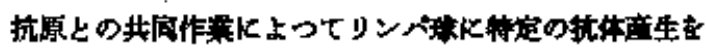

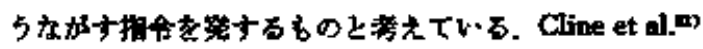

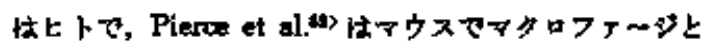

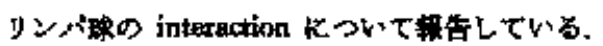

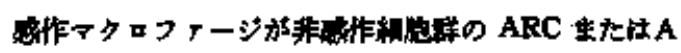
FCP との interaction を虹こすこともあららし, 非

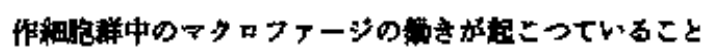

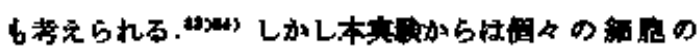
interaction を見ることはでき十推いするのみでかる.

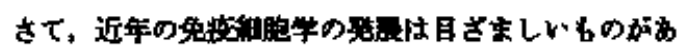
D. T.cell, Bcell, マクロフォーシ 等の interaction

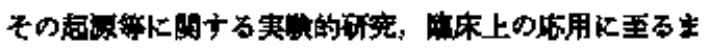

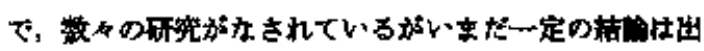

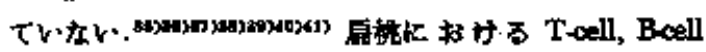

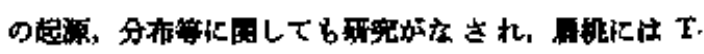

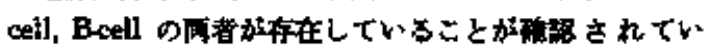
万+ ${ }^{\text {(2) }}$ )

T-cell i仕 Bcell の扰体产生在盼ける helper cell

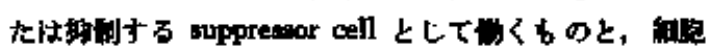

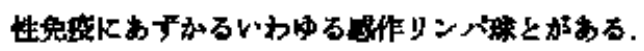

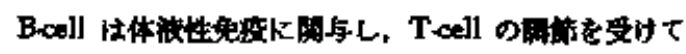

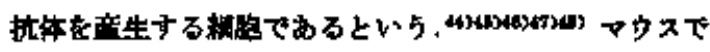

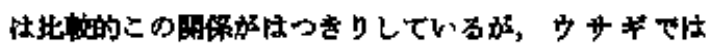

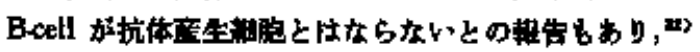

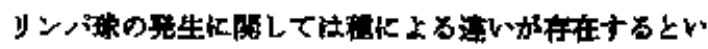

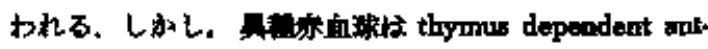


iten とされて过 り，T, B. cell-interaction を是非必要と ナるといかれているい

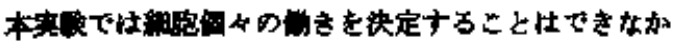

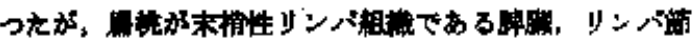

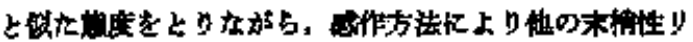

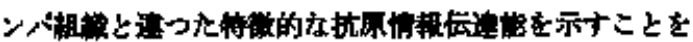

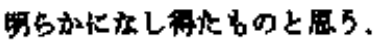

\section{:}

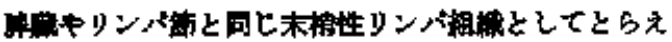

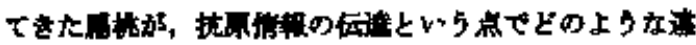

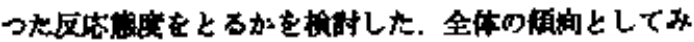

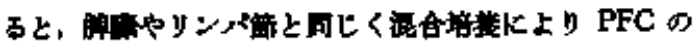

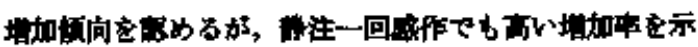

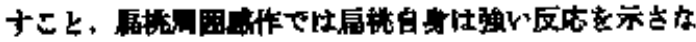

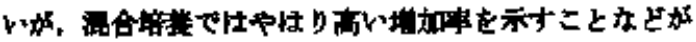

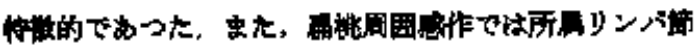

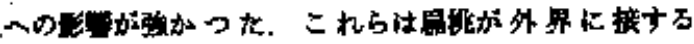
cypt 加抗原を梫讨石 system に九つていること，他

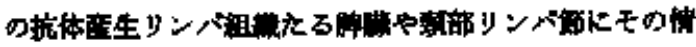

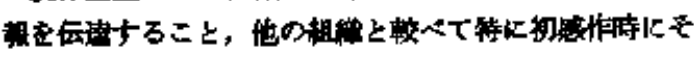

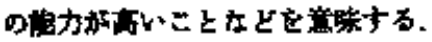

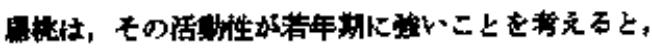

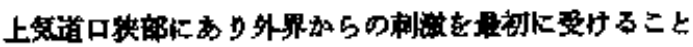

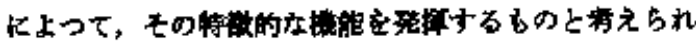
万.

\section{立茄}

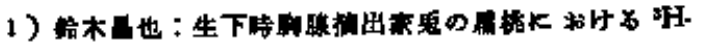

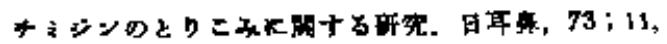
62-74, 1970 .

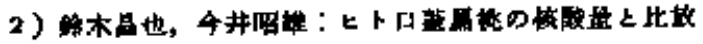

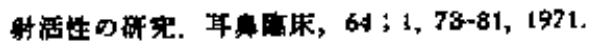

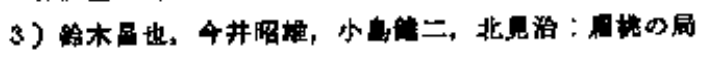

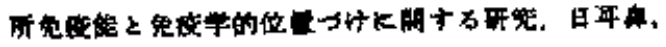
$76 ; 9,1-10,1973$.

4) M. Suxwi \& H, Ino: Relation between Thymas and Toneit. Arch. klin. exp. Ohr,-, Nas,-uKehlk. Heilk, 204: 249-260, 1973.

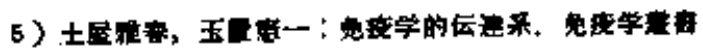
7. 医率害院.

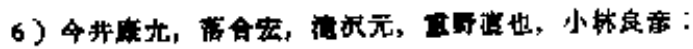

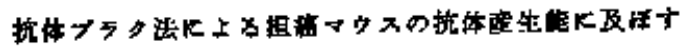

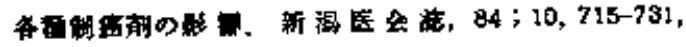
1970.
7) M. Richandson, J.W. Moorhand \& D.C. Resdy: The Secondary Anti-Erythrocyte Response of Rabtit Spleen Cells Stimalated in vitro, Immunalogy i7 ; 630-615, 1969.

B) R.I. Mishdl \& R.W, Dutton: Immumization of Dissociated Spleen Cell Cultures from Normal Mice.

J. Exp. Med, 126 ; 423-412, 1967.

9) N.K. Jorne A.A. Nordin: Plague Formation in Ager by Single Antibody-Produxing Cell. Science 140; 405, 1969.

10) C. Homonen \& A.E. Bussard: Antibody Production by Cello in Tissue Culture. J. Exp. Med. 123 ; 1035-1051, 1966.

11) R.I. Mishell \& R.W, Dutton: Immunization of Nomas Mouse Spleen Cell Suspension in Vitro. Science 153 ; 1004-1005, 1966.

13) J.W. Dymisski \& B.F, Argyris; in Vitoo Seasitixation to Transplantation Antigens, Transplantation 11 ; 6, 514-520, 1971.

13) M.F. Greaves, SJ.T. Owen \& M.C, Raff: $\mathrm{T}$ and B Lymphocyter, Excerpta Medica.

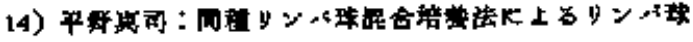

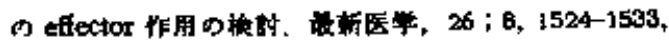
1971.

16) J.W. Hhe a M.S. Finkelsterin: Antibody Formation initiated in 'Vitro. J. Exp. Med. $117 ; 457-477$, 1963.

16) S.E. Suehag \& B. Afondd: The Fonsation and Properties of Poliovirus-neutralizisig Antibody J. Exp. Med. $119 ; 31-39,1964$.

17) N.D. Chapman i R.W. Datron: The Stimulation of DNA Systhesis in Cultures of Rabbit Lymphnode and Splees Cels Suspensions by Homologors Cells. J. Exp. Med. $121 ; 85-101,1965$.

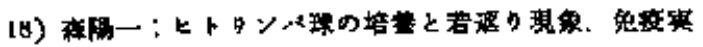

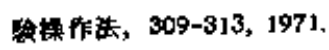

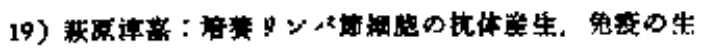

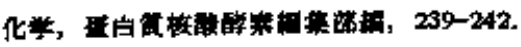

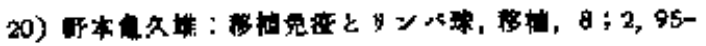
104, 1973.

21) P. Lonai \& M. Reldmen: Cocoperation of Lym. phoid Cells is an in vitro Graft Reaction System. Trassplastation 11 ; 5, 446-456, 1921. 
22) B. Bain, M. Vas \& L. Lowenstein: Federation Proc. $22 ; 428,1663$.

23) R.W. Dutton: Further Studies of the Stimulation of DNA Synthesis in Cultures of Spleen Cell Suspensions by Homologous Cells in Inbred Strains of Mice and Rats. J. Exp. Med. 122 ; 759-770, 1965.

24) K. Hirschhorn, F. Bach \& R.L. Kolodny: Immune Response and Mitosis of Human Peripheral Blood Lymphocytes in Vitro. Science $142 ; 1185-$ $1187,1963$.

25）平野真司：溶血斑形成細胞：最新医学, $24 ; 3$. 1436-1449, 1969.

26) L. Surjän, Sen, L, Surján Jr. \& M. Surján:

Further Investigations into the Immunological Role of Tonsil. Acta Otolaryng. 73 ; 222-226, 1972.

27) 中村国衛：IgG 産生形質細胞の增殖を伴 5 in vitro 兔疫系の樹立々抗原認識に拈ける胸腺 RNA の役割. アレルギー . $23 ; 3,263-264,1974$.

28）浜岡利之: 免疫記憶細胞. 最新医学, $24 ; 7,1460-$ $1468,1969$.

29) M. Fishman: Antibody Formation in Vitro. J. Exp. Med. $114 ; 837-856,1961$.

30) F.L. Adler, M. Fishman \& S. Dray: Antibody Formation Initiated in Vitro. J. Immunol. $97 ; 4$, 554-558, 1966.

31) M.J. Cline \& V.C. Swett: The Interaction of Human Monocytes and Lymphocytes. J. Exd. Med. ; 1309-1325, 1968.

32) C.W. Pierce \& B. Benacerraf: Immune Response in Vitro. Science $106 ; 1002-1004,1969$.

33）三檑進，大町和千代：マクロファーシと抗体産生.

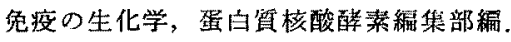

34) D.E. Mosier: A Requirement for Two Cell Types for Antibody Formation in Vitro. Science 158; 22, $1573-1575,1967$.

35）皇山茂：抗体産生細胞。乍疫，医科研七ミナ一

36）佐渡敏彦: 抗体應生細胞の增殖々分化。免没，医科 加七ミナー

37）入交清博：リンバ節ならび飞胸管内和胞の抗体廒 生. 罗新医学, $24 ; 7,1450-1459,1969$.
38) J.F.A.P. Miller \& G.F. Mitchell: Cell to Cell Interaction in the Immune Response. J. Exp. Med. $128 ; 801-820,1968$.

39) G.F. Mitchell \& J.F.A.P. Miller: Cell to Cell Iateeaction in the Immune Response. J. Exp. Med. $128 ; 821-837,1968$.

40) N.I. Abdou \& M. Richter: Cells involved in the Immune Response. J. Exp. Med. 129 ; 757-774, 1969. 41) N.L. Abdou \& M. Richter: Cells involved in the Immune Response. J. Exp. Med. 130 ; 141-163, 1969.

42）田端敏秀，榎本雅夫，岡本進：家鬼扁桃の免度能に 関する研究。耳鼻湢床，66；8,889-893，1973.

43）田端敏秀，樘本雅夫，藤村直樹，平松惠三：ヒト扁 扇の免疫機能。耳楞臨床，66；8，895-900, 1973.

44) D.J. Raidt, R.I. Mishell \& R.W. Dutton: Cellular Events in the Immune Response. J. Exp. Med; $681-698,1968$.

45）奥村康：兔疫グロブリン産生の維御者としての胸 腺. 最新医学, $28 ; 7,1262-1269,1973$.

46）尾然越文亮：リンパ球の增殖様式とくにDNAの合 成蘊路について。最新医学，26；8，1456-1463，1971. 47）武谷健二：T細胞と B 細胞。日本医会誌，70；3， 253-258, 1973.

48) G.F. Mitchell \& J.F.A.P. Miller: Immunological Activity of Thymus and Thoracic-duct Lymphocytes. Proc. Nati. Acad. Sci. U.S. 59 ; 296-303, 1968.

49) 矢田純一：T細胞之B 細胞。鼠新医学, $28 ; 7$, $1256-1261,1971$.

辫を終るにあたり，終始御指首を頂き，御高閲を睗わ つた恩師猪初男教授に深謝いたしますまた実験に劦力 いたたきました教室扁桃研姿班の諸先生に感謝いたしま 5 .

本諭文の要旨は，第13回，第14回日本扇桃研究会に発 表した。

なお本研究は文部省科学研究費の補助を受けた（昭和 49 年度一般研究 948080 号)

（原稿受付 昭和49.9.21日) 